\title{
The Legality of Small Arms Production:
}

\section{An Obstacle to Effective Trade Regulations?}

\section{Nicola Piccini}

MSc in Global Crime, Justice and Security

\begin{abstract}
Officially, international control of small arms and light weapons (SALW) has made considerable advancements in recent years, most notably in the form of the 2014 Arms Trade Treaty (ATT). Nonetheless, important systemic and structural deficiencies seem to persist, which prevent these control mechanisms from achieving their intended purpose. In an attempt to find an explanation for these shortcomings, this article traces back previous attempts aimed at combatting the illicit proliferation of SALW, by emphasising both their unbowed demand and the trade's continuous commercial viability. The example of Bulgarian-made AK-47 machineguns underlines the picture of a system intentionally failing to prevent the weapons' profitable export. It concludes that following the rise of globalisation, the privatisation of SALW manufacturing industries appears to have become the biggest impediment to effective control. Subsequently, it is argued that most anti-proliferation treaties are deliberately limited to a priori insufficient trade restrictions, as they lack any pre-emptive measures that target these weapons' mass production in the first place. Once produced, SALW will find a buyer - no matter the existence of trade restrictions.
\end{abstract}

Keywords: Small Arms Trade, Trade Regulation, SALW 


\section{Introduction}

The past thirty years have witnessed increased attention brought to the global proliferation of small arms and light weapons (SALW) due to their recognition as the primary cause of death in conflict situations since the end of the Cold War, with women and children being disproportionally affected (Lustgarten 2015; Bolton, Sakamoto \& Griffiths 2012; Killicoat 2006). Notwithstanding numerous attempts to combat their illicit distribution and misuse (Bolton, Sakamoto \& Griffiths 2012; Greene 2000), including the arguably most extensive multinational agreement to this day, the 2014 Arms Trade Treaty (ATT) (Lustgarten 2015), these deadly weapons still regularly find their way into in the hands of child soldiers, insurgents, and terrorists around the globe (Hanson 2011; Marsh 2002).

Confronted with the question as to why these efforts frequently do not seem to achieve their aspired goals, this essay shifts the attention away from the focus on trade regulations towards a more fundamental issue: the widespread legality of semi-private and mass-market production of SALW (Small Arms Survey 2014; Bolton, Sakamoto \& Griffiths 2012).

First, an initial account of the global distribution of small arms, their humanitarian impact and market value will be followed by a scrutiny of past trade-focused initiatives aimed at combatting illicit proliferation. Highlighting the fact that the geographic fulcrum of SALW production lies in the Global North, the essay then proceeds to analyse the key impact of increased privatisation and globalisation on Western small arms manufacturing industries in the post-Cold War era (Bolton, Sakamoto \& Griffiths 2012; Marsh 2002). The developments in this period have since proved seminal for the efficacy of trade-focused arms treaties.

The findings are exemplified by the semi-private Bulgarian production of AK-47 type assault rifles, which in spite of existing treaties and embargos were found to have been provided to questionable clients in conflict zones all over the globe (Lustgarten 2015; Hanson 2011; Killicoat 2006; Kiss 2004; Greene 2000). In conclusion, the evidence provided reveals how the scrutiny of the mass-market production of small arms can offer an explanation for the 
shortcomings and resulting ineffectiveness of the current mechanisms aimed at combatting the illicit proliferation and misuse of SALW. These mechanisms are usually limited to arms trade and fall short of having any pre-emptive effects.

\section{The impact of SALW}

This segment analyses five aspects pertinent to SALW trade definitional range, their availability, potential for harm, and the lucrative business related to both their production and trade. Given the existence of diverging definitions of SALW (Lustgarten 2015; Bolton, Sakamoto \& Griffiths 2012; Efrat 2010), Greene's (2000, p. 154) comparatively wide interpretation will serve as a base line for the following analysis:

[...] the term "small arms" refers to conventional weapons produced (if not used) for military purposes that can be carried by an individual, including pistols, rifles, sub-machine guns, assault rifles and grenades. Light weapons can be carried on a light vehicle, and operated by a small crew. They include heavy machine guns, light mortars, and shoulder-fired anti-tank or anti-aircraft missiles.

However, this definition is not sufficient in that it does not encapsulate military grade training and ammunition. Despite ammunition and training technically not falling under the umbrella term of SALW, they should be considered an important part of any discussion on SALW; a detail obscured by Greene's (2000) definition. In this way this essay views SALW not as solely manufactured objects but an institutionalised regime consisting which holds substantial symbolic and social values. This paper borrows Krassner's (1982) definition of regime as a social construct consisting of 'principles, values, norms, rules and decision-making procedures around which actors' expectations converge in a given issue area'. These factors all work towards the proliferation and use of SALWs to cause harm. Because the problem of SALW extends the mere material manifestations of weapons, trade-regulations are inherently flawed. Instead, an upstream approach focussing on the legality of the SALW regime is in order. SALW are present in the 
majority of countries worldwide, with their legitimate possession being 'intimately connected to' a state's 'inherent right of self-defence' (Lustgarten 2015, p. 570).

Consequently, approximately 'eight million new small arms and up to 15 billion rounds of ammunition' (Amnesty International 2017) find their way into the global markets each year, both the licit and illicit (Boutwell \& Klare 1998), adding to an estimated total of 875 million units in circulation today (Small Arms Survey 2018b; Amnesty International 2017). Yet even the Small Arms Survey, in its function of keeping track of global SALW sales and conflict-related developments, has repeatedly stated that despite best attempts to deliver accurate numbers, the actual trade is likely to be considerably higher (Small Arms Survey 2014).

While not suggesting a simplified causal relationship between gun ownership and violence, this extensive distribution has been known to facilitate conflict (Lustgarten 2015). Boutwell and Klare (1998) found that global armed conflicts in the past 30 years were not dominated by heavy military equipment but by SALW defined by Greene (2000). SALW not only caused the majority of casualties, but their usage has been tied to the displacement of millions of refugees in politically unstable regions, predominantly in the Global South (Krause 2001, cited in Bolton, Sakamoto \& Griffiths 2012; Boutwell \& Klar 1998). As a result, these cumbersome milestones earned them the title of 'the real weapons of mass destruction' (Annan 2000, cited in Lustgarten 2015 p. 571; Bolton, Sakamoto \& Griffiths 2012).

Yet despite their destructive potential, small arms also mean lucrative business for those involved in their production and distribution, which has been found to represent a key obstacle to the efficacy of any type of agreement aimed at curbing their proliferation. In 2018, the authorized trade in SALW alone was estimated at approximately US $\$ 8.5$ billion (Small Arms Survey 2018b; Amnesty International 2017), representing a drastic increase compared to 2002, where Marsh's (2002) research, based on the Small Arms Survey's most recent data at the time, allocated the number to lie between US\$4-6 billion (2002). Given the inherent complexity and the secrecy veiling the black markets' intricate workings (Marsh 2002; Greene 2000), the profits generated by 
the illicit trade were estimated to range 'from 10-20' to ' 55 percent of the legal trade' in 2002 and most likely do not reflect the current reality (Dyer \& O'Callaghan 1998, cited in Marsh 2002, p. 220).

Shifting attention to the production of SALW, it is important to understand who benefits the most from their global trade. While disregarding 'craft production' at this point, done 'largely by hand' and 'in relatively small quantities' (Small Arms Survey 2018a), the industrial production of small arms in particular has expanded drastically since 1990, both quantitatively and geographically. Throughout most of the $20^{\text {th }}$ century small arms manufacturing used to be the specialty of a handful of powerful state-affiliated producers, disproportionally located in the US, Russia and China (Marsh 2002). The standoff between the former two countries spurred state production of various types of firearms in during the Cold War, including SALW. Yet as will be addressed further below, the end of this Arms Race had a landslide effect for the weapons producing industry around the globe.

Today, 'nearly 1,250 companies', both private and semi-private, operate in more than 90 countries (Stevenson, n.d., cited in Bolton, Sakamoto \& Griffiths 2012, p. 304), with the world's top ten producers of SALW all surpassing annual revenues of US\$100 million, and predominantly residing in North America, Europe, Asia and Russia (Small Arms Survey 2014).

SALW therefore contribute substantially to harm and conflicts around the world and represent a challenge that needs to be addressed accordingly. Because SALW should rather be seen as an institutionalised regime as opposed purely material objects, existing arms control regimes fall short of having an impact. This will be shown in the next section.

\section{The (insufficient) focus on trade regulations}

This section comprises a short summary of noteworthy attempts to combat the illicit proliferation of SALW. After a recollection of past efforts, the Arms Trade Treaty of 2014 will be 
scrutinised in more depth, in order to set the stage for a range of potential issues inherent to their collective approaches.

In the 1990s the uncontrolled diffusion of small arms became recognised as morally objectionable and as posing a potential threat to international security and regional stability (Bolton, Sakamoto \& Griffiths 2012; Efrat 2010; Greene 2000). This spurred the UN and various international humanitarian organizations to generate support for collective control measures focused on SALW traffic and transfer (Spapens 2007, p. 359). This stemmed from the growing awareness of some leading political individuals - like former UN General Secretaries Boutros Boutros-Ghali and Kofi Annan - that most of the weapons used and responsible for disastrous human agony worldwide (especially in many African countries) predominantly originated form the Global North (Lustgarten 2015). Yet due to their inability to meaningfully affect the production of said weapons, attention was focused on restricting their use and controlling their trade instead.

Besides the UN, other groups and organizations became active in creating new regulative initiatives as well, such as: [..] the European Union (EU), Organisation of American States (OAS), Mercosur, Organisation of African Unity (OAU), Southern African Development Community (SADC), [or] the Economic Community of West African States (ECOWAS) (Greene 2000, p. 151).

Some of the more 'substantial regional initiatives' made good progress and achieved partial success (Greene 2000, p. 187), like the 'curbing [of] gun violence' by African governments (Efrat 2010, p. 128) through treaties like the ECOWAS SALW trade moratorium in 1998 (Greene 2000). Yet others such as the EU's Code of Conduct for Arms Exports (Bolton, Sakamoto \& Griffiths 2012), as well as numerous international embargoes (Marsh 2002) were repeatedly criticised for being 'weak and ineffective' (Efrat 2010, p. 98), or 'well-intentioned' but feeble (Jones 1988 cited in Marsh 2002, p. 220). 
These critiques frequently centred on a repeated lack of 'binding financial or legal obligations' (Greene 2002, p. 172) and crucial 'enforcement mechanisms' (Greene 2002, p. 173), resulting at times in a display of plain disregard for the restrictions agreed on. The handling of foreign arms licensing by the UK serves as a good example. Amongst other prominent international infringements, the British government was found to have circumvented a UN arms embargo imposed on Sierra Leone in 1998 (Marsh 2002) and to have supported 'purported' sales of British weapons to 'Jordan in the late 1980s that were actually to Saddam Hussein's Iraq' (Lustgarten 2015, p. 573).

\section{The Arms Trade Treaty}

In an attempt to finally create a legally binding, international agreement that would prevent state-to-state transfers of conventional weapons when known that they might 'be used to commit or facilitate genocide, crimes against humanity, or war crimes' (Amnesty International 2017; Small Arms Survey 2013, p. 1), 154 states accepted and approved the 'text of an Arms Trade Treaty' (ATT) in 2013 (Lustgarten 2015, p. 569). The US then voted against it and other leading arms manufacturing nations like Russia, China and India abstained (Lustgarten 2015, p. 576).

Even with these key producing countries abstaining, the ATT arguably represents an unprecedented achievement in the realm of SALW control, but its actual wording conceals major barriers to its applicability. In fact, upon a closer look, considerable inconsistencies and weaknesses regarding the ATT's scope and the obligations become quickly apparent (Small Arms Survey 2013).

Whereas seemingly covering a broad range of conventional types of weapons, including SALW, missiles and missile launchers, the exclusion of categories like military grade training and transport as well as surveillance equipment all represent serious defects (Lustgarten 2015). This is particularly problematic, given that the latter frequently form part of repressive regimes' arsenals and are thus 'likely to be used in ways and for purposes that the Treaty supposedly sought to prevent (Lustgarten 2015, p. 587). 
Yet the potentially most unsettling point besides these missing items, as well as a generally narrow focus on 'export, import, transit or transhipment' regulations (Small Arms Survey 2013, p. 2), is its lacking rigor where of absolute necessity for it to make a significant difference. Despite the inclusion of arguably stern requirements that need to be fulfilled before a private armsexporting deal can be authorized by its respective government (Small Arms Survey 2013), the ATT's (UNGA 2013) Article VI and VII's ambiguous language continues to leave loopholes for deviations. For example, article VII(1) stipulates that signatories should:

[...] in an objective and non-discriminatory manner, taking into account relevant factors, including information provided by the importing State in accordance with Article 8 (1), assess the potential that the conventional arms or items:

(a) would contribute to or undermine peace and security;

(b) could be used to:

(i) commit or facilitate a serious violation of international humanitarian law;

(ii) commit or facilitate a serious violation of international human rights law;

(iii) commit or facilitate an act constituting an offence under international conventions or protocols relating to terrorism to which the exporting State is a Party; or

(iv) commit or facilitate an act constituting an offence under international conventions or protocols relating to transnational organized crime to which the exporting State is a Party.'

Therefore, the ATT enables countries to base their decision on whether a trade agreement fits the ATT's standards on a number of subjective 'factors that are irrelevant, and may well be contrary, to the objects and purposes of the Treaty' (Lustgarten 2015, p. 591). Arms-manufacturing 
and exporting countries' governments are practically allowed to assess for themselves, based on their nationally gathered intelligence, whether or not their weaponry could 'contribute to or undermine international peace and security', which only then would represent a relevant transfer obstacle (Lustgarten 2015, p. 591).

The resulting liability to individual interpretation in borderline cases and sheer narrowness of scope, as well as the repeated non-incorporation of an effective enforcement apparatus (Lustgarten 2015) might be reasonably seen as self-supporting problems, but as it will now be argued, they actually represent but extensions of a more fundamental issue.

Costly international agreements that aim to combat the negative humanitarian effects of SALW's uncontrolled proliferation do not address their root issue of the legality of their, often private, mass-market origin (Efrat 2010). No matter how despicably firearms are used, how many regulations are broken, and embargoes ignored, the chances for them to have been produced absolutely legally in the first place are disproportionally high (Spapens 2007; Stohl 2005; Marsh 2002). Most guns trafficked and/or misused originate from either legally manufacturing industrial companies, private gun holders, or government arsenals and their disposal of 'surplus' arms (Greene 2000, p. 153).

And even if one was to focus on trade restrictions alone, as exemplified by the earlier mentioned treaties, and despite wide criticism arguing for the inefficiency of such myopic approaches (Bolton, Sakamoto \& Griffiths 2012; Greene 2000), 'licit and illicit trade cannot so easily be disaggregated' (Krause 2002, cited in Bolton, Sakamoto \& Griffiths 2012, p. 306). It is an 'open secret that many governments are deeply implicated in much of the illicit arms trade, either by facilitating covert supply to proxies and allies or by turning a "blind eye" to the diversion into the black market' (Stohl 2005; Greene 2000, p. 151). 
The next chapter thus takes a step back and tries to scrutinize how private SALW manufacturing evolved after the end of the Cold War and how global arms manufacturing companies arguably managed to reach a position outside the reach of effective control.

\section{Impact of privatisation and globalisation on SALW production}

With the end of the Cold War the aforementioned system of a limited number of 'state monopolies of violence', responsible for the lion share of global weapons production, opened up to a more market-based, liberal 'political economy of arms trafficking' (Bolton, Sakamoto \& Griffiths 2012, p. 305; Kiss 2004).

While 'private arms manufacture and brokerage' (Thayer 1969, cited in Bolton, Sakamoto \& Griffiths 2012, p. 305) had existed well before the fall of the Iron Curtain in 1989, the following waves of privatisation of formerly state-owned industries, and increased 'economic liberalization and improvements in communication and transportation' (Efrat 2010, p. 126) had a decisive impact. Paired with 'dramatic socio-economic transitions' (Kiss 2004, p. 1), the sudden drop in states' military demand for small arms led to an 'increased pressure on arms companies to export' (Bolton, Sakamoto \& Griffiths 2012, p. 305). Luckily for them, the $21^{\text {st }}$ century woke up to a changing political landscape and the global rise of 'low- to medium-intensity modern civil' conflicts (Small Arms Survey 2007, p. 269) and as a result the mass-market production of SALW rose anew.

After having overcome the initial fears of losing their 'markets, subsidies, and privileges' due to the 1990s' 'major economic recession, fundamental political changes' and 'redefined national military and security interests' (Kiss 2004, p. 1), the businesses involved benefitted from an opening of the market. Weapons became increasingly treated like regular commodities, to be traded and sold on global markets according to the guiding principles of demand and supply (Killicoat 2006). With indiscriminate sales predominantly based on profit-driven calculus (ibid.), the growing demand frequently led to disregard for 'the negative effects of their business' (Efrat 2010, p. 127), despite some of it originating from 'rebel groups, [or] organized crime networks in 
armed' conflict zones (Boutwell, Klare \& Reed 1995, cited in Bolton, Sakamoto \& Griffiths 2012, p. 305; Sköns \& Weidacher 2000).

Yet focusing on private arms companies alone only explains half of the dynamic, as they are frequently co-owned by their host states, who at times have been known to encourage even less than popular or ethical sales to promote their own agenda (Lustgarten 2015, p. 570).

In their respective works Bolton, Sakamoto and Griffiths (2012) and Stohl (2005) describe how easily the lines between legal and illegal trade can blur. 'Clandestine deals' between illicit arms traders and legal manufacturers can 'open up untapped supply' for questionable clients while providing lucrative opportunities for the producers (Griffiths \& Wilkinson 2007, cited in Bolton, Sakamoto \& Griffiths 2012, p. 305; Greene 2000). By facilitating such illicit transactions, the producing states' governments are able to trade with the 'underworld with limited political backlash, shielded by opaque supply chains' (Griffiths \& Wilkinson 2007, cited in Bolton, Sakamoto \& Griffiths 2012, p. 305). Using private companies as middlemen removes their 'own large fingerprints on the arm sales' (Hanson 2011, p. 144). In his research, Greene found that governments often deliberately facilitate 'excessive and destabilising flows and accumulations' of SALW because of their own economic or political motivations abroad (2000, p. 182; Marsh 2002). A look at the production and impact of Bulgaria's AK-47 rifle exports illustrates this complex interplay of state and private interests and its impact on the feasibility of restrictive international trade regulations (Killicoat 2006).

\section{The AK-47 Kalashnikov and its European reproduction}

The AK-47 Kalashnikov assault rifle, named after its inventor Mikhail Kalashnikov (19192013) and initially produced exclusively in the former Soviet Union, has long defended its reputation as the most popular and deadly fire arm ever created (Freeman 2019; Blair 2015; Hanson 2011). With estimates ranging from 50 to 100 million units related to this category in circulation today, since its release in 1947 (Small Arms Survey 2007), it represents the most 'ubiquitous weapon in the history of firearms' (Blair 2015; Hanson 2011, p. 144). 
Large parts of its unbroken success are owed to its simplicity, cheap price, longevity and reliability; regardless of the operating conditions (Hanson 2011; Small Arms Survey 2007). And despite some albeit contested (Hanson 2011) critique regarding its comparatively lesser accuracy, user safety and limited range (Killicoat 2006), it has been the 'weapon of choice for armed forces' in about 80 countries as well as of 'non-state actors alike' (Jane's Information Group 2003, cited in Small Arms Survey 2007, p. 258).

Besides having played a key role in a majority of insurgencies and guerrilla combats 'in Asia, Latin America, and [...] Africa' in the last 30 years (Hanson 2011, p. 145; Small Arms Survey 2007), roughly '250,000 people per year' are estimated to fall victim to its use (Freeman 2019). A development which led Chivers (2010) to the 'dispassionate' conclusion that rarely an invention had "done so much to kill so many through "war, terror, atrocity, and crime"" like the AK-47 (cited in Hanson 2011, p. 145).

Yet due to it not being patented (Killicoat 2006, p. 3), others besides the Soviet Union soon sought to produce the weapon themselves motivated by its reliability in battle (Hanson 2011). These states include the US, China and many Eastern European countries (Freeman 2019; Kiss 2004). Today Poland, Hungary, Romania and Bulgaria all situate companies, both private and at least partly state-owned, which produce and export rifles of the AK type (Freeman 2019; Small Arms Survey 2007). For illustrative purposes however, a closer look at the partly state-owned Bulgarian company of Arsenal Co will reveal the gravity and implications of the discussed issue. As of 2019 the country has become Europe's number one exporter of Kalashnikovs (Freeman 2019).

During the transitory years of the 1990s and driven by the mentioned need to find new clients, 'save the industry and provide the country with indispensable hard currency earnings', the Bulgarian state initiated a rigorous 'arms export policy' which led to large-scale exports (Freeman 2019; Small Arms Survey 2007, p. 17). Despite its acceptance into NATO in 2004 led to a 
tightening of its export controls, many of its prior foreign sales were found to have had dire humanitarian consequences (Small Arms Survey 2017). In a way, the damage was already done.

While only portraying a short and by no means all-encompassing list, thorough investigations into Arsenal Co's past trades conducted by The Telegraph and The New York Times

revealed numerous infringements of international trade agreements. Shipments of ' 35 tons of weapons' were exported to 'a group of rebels in Sierra Leone' (Freeman 2019) in 1998, despite documents claiming Nigeria as the original destination. AKs sold to the Saudi government were allegedly channelled into 'the killing fields of Syria and Yemen' (Freeman 2019). Even the Islamic State in Iraq and Syria (ISIS) ended up getting access to relinquished Arsenal weapons in Mosul in 2014 and purportedly legal exports to Uganda were quickly resold illegally to supply the 'bloodcurdling civil war' in South Sudan (Freeman 2019; Small Arms Survey 2007).

Finally, it is vital to consider that roughly ' 90 per cent' of Arsenal's massive and mostly 'military-related' production is sold abroad to 'Asia, Africa, and the Middle East' (Kiss 2004, p. $35)$. Virtually no European armed force nor NATO currently employs and thus requires AK-47s for their own defense purposes (Military Factory 2019; Hanson 2011), partly and arguably because of pride and 'national chauvinism' barring European SALW manufacturing bastions like Germany, the UK or Italy to accept and accredit their former competitor's prime product's proficiency (Hanson 2011, p. 145).

\section{Conclusion}

The paper's main line of argument has been of a simple nature: Once a product of a particular popularity is produced, it will inevitably reach its wider customer base unleashing a process which is hard enough to control if the main actors involved actually willed it, yet impossible if they do not. Therefore, framing SALW as an international regime could provide a more holistic account of the problem. 
Here, the evidence collected suggests a lack of wholeheartedness of SALW-producing countries in their attempts to effectively restrict potentially dangerous individuals from getting access to weaponry. In order to find a plausible answer for the resulting feebleness of, and lacking commitment to the various trade-based agreements many producing states ostensibly adhere to, I scrutinized the impact of both globalisation and privatisation on SALW manufacturing industries after the Cold War.

While the causal link between the political and/or profit-driven interests of state-owned and private industries, and the ineffectiveness of current trade-focused treaties might have been presented as too simplistic as to do justice to the actual complexity of illicit SALW proliferation, I argue that the findings do hint in this direction.

To this day, most trade-based initiatives aimed at preventing illicit access and misuse of firearms, including the ATT, have effectively failed to achieve their aspired goals to a satisfying degree. Not only have some of them been found to be ill equipped on a technical side but none of them address the elephant in the room, namely the legal origin of most small arms traded, whether legally or illegally. The complexity and implications of this issue were underlined by the example of Bulgarian AK-47 type rifles, produced not for the host country's or its allies' self-defense, but sold and exported mainly for profit, regardless of allegedly questionable final destinations.

Finally, both the current shape of international arms trade treaties and a glimpse at some of their members' ulterior motivations and practices do paint a worrisome picture regarding the prior's likelihood and ability to prevent the society's weakest members from the illicit proliferation and misuse of SALW. 


\section{References}

Amnesty International 2017, Killer Facts: The Scale of the Global Arms Trade, viewed 3

December 2019, $<$ https://www.amnesty.org/en/latest/campaigns/2017/09/killer-facts-thescale-of-the-global-arms-trade/>.

Annan, K 2000, 'Freedom from Fear: Small Arms', Report of the Secretary-General to the Millenium Assembly of the United Nations, UNGA, New York viewed 3 December 2019, $<$ https://www.un.org/en/events/pastevents/pdfs/We_The_Peoples.pdf $>$.

Blair, D 2015, AK-47 Kalashnikov: The firearm which has killed more people than any other, viewed 3 December 2019, <https:// www.telegraph.co.uk / news/ worldnews/ northamerica/ usa/ 11714558/ AK-47-Kalashnikov-The-firearm-which-has-killed-morepeople-than-any-other.html $>$.

Bolton, M, Sakamoto, EE \& Griffiths, H 2012, 'Globalization and the Kalashnikov: PublicPrivate Networks in the Trafficking and Control of Small Arms', Global Policy, vol. 3, no.3, pp. 303-313, DOI 10.1111/j.1758-5899.2011.00118.x.

Boutwell, J \& Klare, M 1998, 'Small Arms and Light Weapons: Controlling the Real Instruments of War', Arms Control Today, vol. 28, no. 6, pp. 15-23, viewed 15 August $2020,<$ https://search.proquest.com/docview/211216338?accountid=10673 $>$.

Boutwell, J, Klare, M \& Reed, LW (eds.) 1995, Lethal Commerce: The Global Trade in Small Arms and Light Weapons, American Academy of Arts and Sciences, Cambridge.

Chivers, CJ 2011, The gun, Simon and Schuster, New York.

Dyer, S \& O'Callaghan, G 1998, Combating Illicit Light Weapons Trafficking: Developments And Opportunities. London: British American Security Information Council, London, no. 3, viewed 15 August 2020, $<$ https://www.files.ethz.ch/isn/57319/1998combatingillicit.pdf $>$.

Efrat, A 2010, 'Toward Internationally Regulated Goods: Controlling the Trade in Small Arms and Light Weapons', International Organization, vol. 64, no. 1, pp. 97-131, DOI 10.1017/S0020818309990257.

Freeman, C 2019, 'Licensed to kill: The Kalashnikov centre of Europe', viewed 3 December 2019, < https:// www.telegraph.co.uk / news/ licensed-to-kill/>>.

Greene, O 2000, 'Examining international responses to illicit arms trafficking', Crime, Law and Social Change, vol. 33, no. 1, pp. 151-190, DOI 10.1023/A:1008398420612.

Griffiths, H \& Wilkinson, A 2007, Guns, Planes and Ships: Identification and Disruption of Clandestine Arms Transfers, SEESAC, Belgrade. 
Hanson, VD 2011, 'The World's Most Popular Gun: The Long Road to the AK-47', The New Atlantis, no. 32, pp. 140-147, viewed 15 August 2020, < www.jstor.org/stable/43152665>.

Jane's Information Group 2003, Jane's Infantry Weapons: Yearbook 2002-2003, Jane's Information Group, Coulsdon.

Jones, S 1988, 'EU and U.S. Codes of Conduct on Arms Transfers: Status and Review', The Monitor Nonproliferation, Demilitarization, and Arms Control, vol. 4, no. 4, pp. 23-31.

Killicoat, P 2006, 'Weaponomics: The Economics of Small Arms', IDEAS Working Paper Series from RePEc, pp. 1-28, viewed 15 August 2020, $<$ https://www.csae.ox.ac.uk/materials/papers/2006-13text.pdf $>$.

Kiss, Y 2004, 'Small Arms and Light Weapons Production in Eastern, Central, and Southeast Europe', Small Arms Survey Occasional Papers, no. 13, pp. 1-54, viewed 3 December 2019, $<$ http:// www.smallarmssurvey.org / weapons-and-markets/ producers/ industrialproduction.html $>$.

Krasner, S 1982, 'Structural causes and regime consequences: regimes as intervening variables', International organization, vol. 36, no. 2, pp.185-205, DOI 10.1017/S0020818300018920.

Krause, K 2001, 'Norm-Building in Security Spaces: The Emergence of the Light Weapons Problematic', GERSI/REGIS Working Papers 11, viewed 21 May 2012, $<$ https://depot.erudit.org/bitstream/000854dd/1/000257pp.pdf $>$.

Lustgarten, L 2015, 'The Arms Trade Treaty: Achievements, Failings, Future', International \& Comparative Law Quarterly, vol. 64, no. 3, pp. 569-600, DOI 10.1017/S0020589315000202.

Marsh, N 2002, 'Two Sides of the Same Coin? The Legal and Illegal Trade in Small Arms', The Brown Journal of World Affairs, vol. 9, no. 1, pp. 217-228, viewed 15 August 2020, $<$ https://www.jstor.org/stable/24590286>.

Military Factory 2019, Modern Small Arms by Army, viewed 3 December 2019, $<\underline{\text { https:// }}$ www.militaryfactory.com/modern-guns/index.asp $>$.

Sköns, E \& Weidacher, R 2000, 'Arms production' Stockholm International Peace Research Institute (SIPRI) Yearbook, viewed 15 August 2020, $<$ https://www.sipri.org/yearbook/2000/06>.

Small Arms Survey (ed.) 2007, 'What Price the Kalashnikov?: The Economics of Small Arms', in Small Arms Survey 2007: Guns and the city, Small Arms Survey, pp. 256-287, viewed 15 August 2020, <http://www.smallarmssurvey.org/fileadmin/docs/AYearbook/2007/en/Small-Arms-Survey-2007-Prelims-Intro-EN.pdf $>$. 
Small Arms Survey 2013,'The Arms Trade Treaty: A Step Forward in Small Arms Control?', Small Arms Survey Research Notes, no. 30, pp. 1-4, viewed 15 August 2020, $<$ http://www.smallarmssurvey.org/fileadmin/docs/H-Research_Notes/SAS-ResearchNote-30.pdf $>$.

Small Arms Survey 2014, 'Producers of Small Arms, Light Weapons, and Their Ammunition', Small Arms Survey Research Notes, no. 43, pp. 1-4, viewed 15 August 2020, $<$ https://www.files.ethz.ch/isn/182840/SAS-Research-Note-43.pdf $>$.

Small Arms Survey 2018a, Producers, viewed 7 December 2019, $<$ http:// www.smallarmssurvey.org / weapons-and-markets/ producers.html. $>$.

Small Arms Survey 2018b, Weapons and Markets, viewed 3 December 2019, $<$ http:// www.smallarmssurvey.org / weapons-and-markets.html $>$.

Spapens, T 2007, 'Trafficking in Illicit Firearms for Criminal Purposes within the European Union', European Journal of Crime, Criminal Law and Criminal Justice, vol. 15, no. 3-4, pp. 359-381, DOI: 10.1163/092895607X231206.

Stevenson, J (n.d.) 'The Flow of Small Arms and Explosives to Terrorist Groups: EU Challenges and Remedies', UNIDIR EU Background Paper no. 15.

Stohl, RJ 2005, 'Fighting the Illicit Trafficking of Small Arms', SAIS Review of International Affairs, vol. 25, no. 1, pp. 59-68, DOI 10.1353/sais.2005.0018.

Thayer, G 1969, The War Business: The International Trade in Armaments, Simon \& Schuster, New York.

The Arms Trade Treaty 2013, Treaty no. 52373, United Nations Treaty Series, 3013, viewed 3 December 2019,< https://treaties.un.org/doc/Publication/UNTS/No\%20Volume/52373/Part/I-5237308000002803628c4.pdf> 